\title{
THE IMPACT OF THE GLOBAL ECONOMIC CRISIS ON THE POLAND
}

Aleksandra Korczyc

University of Warsaw, Poland.

Email: aleksandra.korczyc@gmailc.com

\author{
Article History: Received on $18^{\text {th }}$ July 2021, Revised on $29^{\text {th }}$ July 2021, Published on $20^{\text {th }}$ August 2021
}

\section{Abstract}

Purpose of the study: This study aims to present the specifics of the global financial crisis, the threats it brings for Poland in the legal sphere, and possible actions to be taken in this area, particularly at the European Union and Poland level.

Methodology: The article uses the historical method and the analysis of documents both at the Polish and European Union levels, including laws, regulations, and decisions.

Main Findings: The scope of the financial crisis in question and its relatively easy transfer between markets entails the necessity to apply extraordinary remedial actions. Poland, through its participation in the European Union, seems to be relatively well protected against the effects of the financial crisis. However, it needs to undertake further structural reforms, in particular reforms of public finances.

Applications of this study: The current study is highly significant for the government of the day in this modern world; the study could be quite effective and meaningful for Higher Education Institutions, government, banks, financial institutions.

Novelty/Originality of this study: Description of the essence of the financial crisis, possibilities of its prevention earlier possibilities of remedial actions at the institutional and legal level, possibilities of obtaining financial support, global analysis of the problem, including its causes.

Keywords: Global Economic Crisis, UE, Poland, Economy, Finances, European Union.

\section{INTRODUCTION}

Expression of the global financial crisis has already entered the everyday language of Poles. We use it as an on-duty bogeyman, treating the financial crisis as an explanation of imaginable economic failures, which could affect our country. Meanwhile, few of us are aware of what economic crisis is and what implications it can have in the sphere of the economic and social life of Poles, much less whether and, eventually, how we can protect ourselves against the crisis using legal instruments available to us now or in the future.

The purpose of this study is to present the specifics of the worldwide financial crisis, the threats it brings to Poland in the legal sphere, and possible actions, which can be taken in this sphere - particularly at the level of the European Union and Poland itself.

\section{CAUSES AND SPECIFICS OF WORLDWIDE FINANCIAL CRISIS}

Among the causes of the current financial crisis are mentioned in the first place, the bursting of the speculative bubble in the mortgage market in the United States, from which the crisis spread around the world. Appearing in this and other speculative bubbles were, among other things, the effect of excessive development of the financial system in the United States, which enabled easy access to credit and allowed sharing among various entities and hide the risk related credited transactions. It allowed the United States to play for many years the role of a global brokerage house, managing huge financial resources, simultaneously distracting the attention of the world from the progressive loss of competitiveness of the American economy, growing for years debt of as well U.S. state as its citizens and also increasing social stratification between the group of the richest Americans and the rest of society). (Surdej A., 2014) With the collapse of the mortgage market, all sore points of the American economy came to light, the credit rating of the United States was reduced, and uncertainty has prevailed on financial markets of the world.

The key to understanding how the financial crisis has spread from the United States to the whole world is the phenomenon of globalization as well as the financial sector itself as of international economic relations in general. The origin of the worldwide financial system, which we know in today's form, dates back to 1973 when United States withdrew from the system of control of capital flows and fixed exchange rates, based on the convertibility of the dollar into gold, adopted in 1944 at a conference at Bretton Woods (Surdej A., 2014). This system was destabilized at the end of the 1960s due to the unstable position of the dollar and insufficient control over speculative capital flows (Heller J., Kotliński K., 2012: 228).

Liberalization of capital flows has coincided with the increase of the openness of economies to the external environment, growth of competition between countries to acquire foreign capital and investment, and technological progress, which facilitated communication and enabled making capital transfers on an unprecedented scale.

The growth of capital connections and increasing correlation of economies are contributing to a situation in which a 
crisis arising in one region of the world is able to spread relatively quickly to other regions. This phenomenon is called the spillover effect (Penny Angkinand A., Barth J. R., Kim H., 2010). Spillover can take the form of contagion; immediate, essential effects of the crisis in many countries occur, which exceed the normal degree of economic connections between countries in the period of the lack of crisis (Wyciślak S., 2012: 244). Contagion took place especially when investors in the same countries hold the same assets. In the situation of panic, they get rid of all assets from a given category. If, for example, Hungary has economic problems and Hungarian forint loses value, investors get rid of the not only forint but also Polish zloty, putting it into the same category of assets as forint. In this way, losses in some markets lead to selloffs in other markets.

In the case of the current financial crisis, it turned out quite quickly that the phenomenon of contagion includes not only financial markets themselves but also the real economy and the sphere of public finances of countries. The crisis of financial markets was accompanied by panic in the markets of stocks, strong depreciation of currencies of developing countries, and also the increase of aversion of banks to risk, manifesting itself in the unwillingness to give interbank lends and tightening criteria of giving credits (Wyciślak S., 2012: 248). In connection with the general climate of uncertainty and the lack of confidence in the markets, these phenomena led to the transmission of crisis to the sphere of the real economy.

Facing the threat of economic collapse, particular states began to introduce expensive programs stimulating the economy as well as actions aimed at stabilizing the financial sector by rescuing banks and increasing liquidity in the interbank market. Thus, states took a large part of credit risk, leading to the transfer of this risk to the sphere of public finances (Wyciślak S., 2012: 249). As a result, the debt of many states has risen rapidly, and their bonds began to be traded higher than bonds of some companies. In the face of insolvency, states and the European Union choose one of two ways: either they print more money and buy their debts (as the United States or European Union), what as a consequence must lead to the rapid increase in inflation and devaluation of own currency, or they introduce drastic savings programs, burdening their citizens with costs of crisis (for example Ireland and Greece) (Surdej A., 2014). However, none of these ways can prevent transferring back to the real economy.

Overcoming the economic crisis is possible only through regaining competitiveness by economies, which can occur at the cost of external creditors (devaluation of own currency means de facto expropriation of foreign investors) or at the expense of own citizens who will have to bear costs of savings programs, accept the rise of taxes and reduction of earnings.

\section{FINANCIAL CRISIS IN EUROPEAN UNION}

The transfer of the worldwide financial crisis to the sphere of public finances showed threats existing in the European Union related to the shape of the economic and monetary union.

Against original assumptions, close integration in the sphere of monetary policy did not go so far together with coordination of fiscal policy, left in principle in the hands of member states (Heller J., Kotliński K., 2012: 228-232). Among states of the eurozone, consent to exceed the maximal level of deficit of public finances and national debt dominated. Some states benefited from such benefactions of the common currency as low inflation or high creditworthiness, running into debts excessively. In the situation of the financial crisis, it led to the rapid growth of debt of these states, the loss of their credit rating, and the questioning foundations of the common currency euro. These states as for example, Greece, as long as they will stay in the eurozone, cannot devalue their currency to regain competitiveness in this way. The only way of overcoming the crisis is for them savings programs with drastic effects, leading to the pauperization of own societies and external financial support, especially from European Union.

\section{POSSIBLE FACES OF FINANCIAL CRISIS IN POLAND}

How does the situation of Poland, which wrestles with an excessive deficit exceeding $3 \%$ gross domestic product (GDP) and with the level of debt approaching dangerously to union and constitutional limit of $60 \%$ in relation to GDP, present itself against this background?

It seems that the eventual spreading financial crisis to Poland can include all three spheres mentioned above, i.e., the financial market, the sphere of public finances, and the real economy. External factors as potential sharpening financial crisis in the eurozone and the United States, speculative attacks on Polish currency, depriving Polish banks of financing by foreign parent companies can overlap on internal problems of Poland related to the condition of the Polish financial market, a situation of public finances and structure of Polish economy.

Developing a crisis in each of the three spheres will require different remedial actions. Below actions will be discussed, which are possible to be taken in the sphere of financial markets and public finances of the state.

\section{FINANCIAL CRISIS IN POLAND - POSSIBLE REMEDIAL ACTIONS}

\section{Crisis of financial market and institutions acting in it}

It is necessary to count an insufficient degree of supervision over this market, resulting mainly from the lack of uniform solutions in this branch within the framework of the whole European Union to the causes of the crisis in financial 
markets. It enabled large-scale speculative activity of some investment funds and rating agencies. Actions are taken recently in European Union, especially the establishment of the European System of Financial Supervisors (ESFS) since January 1 2011, and changes in the decree of rating agencies (Łolik M., 2012: 14-16) are aimed at strengthening supervision over the financial market in whole European Union, so also in Poland.

Specificity of ESFS assumes establishing a network of authorities supervising the financial market, which includes national supervisory authorities and new European supervisory bodies: European Banking Authority, European Securities and Markets Authority, and European Insurance and Occupational Pensions Authority. European supervisory authorities are responsible for coordinating current supervision exercised by national bodies; they can also give binding orders for these authorities. It is of special meaning in the case of supervision over financial institutions with crossregional or even global character, where actions taken at the level of particular states turn out to be often insufficient (Jurkowska-Zeidler A., 2010: 266).

The addition of new European supervisory authorities over the financial market is the European Systemic Risk Board ESRB (Regulation (E.U.) No 1092 of the European Parliament and of the Council, 2010). ESRB should counteract systemic risks in the whole European financial market, supervising the condition of particular financial institutions, indicating threats, and giving not binding recommendations and warning concerning arisen risk (Jurkowska-Zeidler A., 2010: 266-269) for E.U. states.

Above mentioned activities are taken at the level of the European Union strengthen supervision over the Polish financial market exercised so far above all through Polish Financial Supervision Authority. Additional protection of Polish financial market is the activity of Financial Stability Committee established in 2008 (Act of November 7, 2008, on the Financial Stability Committee, Journal Journal of 2008, No. 209, item 1317), which is aimed at ensuring effective cooperation of institutions in the scope of supporting and keeping the stability of national financial system - so it fulfils advisory and coordinating functions.

The activity of institutions supervising and monitoring the Polish financial market cannot prevent eventual crisis phenomena in this market. Extraordinary actions can turn out to be necessary, which consist of indirect intervention in the financial market. It is worth indicating two possible ways of conducting such intervention:

1. Such activities of Polish National Bank as a recapitalization of banks through acquiring the part of their shares or buying securities emitted by banks;

2. The aid of State Treasury for financial institutions (Act of February 12, 2009, on granting aid to financial institutions by the State Treasury, Journal of Laws No. of 2009, No. 39).

In both mentioned cases, the barrier for eventual activities of institutions of a Polish state can be union competition law, which forbids financial aid of state for companies, if such aid disturbs or threatens with disturbing competitiveness (article 107 the Treaty of the Functioning of the European Union - further TFEU) (Treaty on the Functioning of the European Union, Journal U. U.E. C 83, 2010: 47-200). Each time it is necessary to examine at giving aid, if this aid does not bring benefit for a financial institution, which would be not granted by the state for a private investor who is in the same situation (Judgment of the Court of First Instance of March 2, 2012, in joined cases T-29/10 Kingdom of the Netherlands v European Commission and T-33/10 ING Groep NV v European Commission).

It is worthwhile in this place to indicate the possibility of regarding public aid as consistent with the internal E.U. market if it is aimed at "remedying serious perturbations in the economy of Member State" (article 107 section 3 letter b) TFEU). Even in spite of the lack of fulfilment of this premise, the Board, resolving unanimously, can regard the aid as consistent with the internal market if "exceptional circumstances justify such decision" (article 108 section 2 paragraph 3 TFEU). Eventual support for the financial sector from public funds will always be subject to examination through union institutions. Sometimes, it can be granted only with the consent of these institutions.

The European Union, as in Poland, works on the introduction of so-called procedure resolution last, which makes orderly restructuring or liquidation of banks with the participation of institutions of state possible. On June 6, 2012, European Commission presented the draft of the so-called directive RRP (from resolution and recovery plan), which enables introducing a procedure of early intervention towards banks, which does not fulfil financial criteria (Gadomski W., 2016). On July 26 2012, in the seat of the Bank Guarantee Fund, ideas of Polish solutions in this scope prepared by the World Bank were presented. The introduction of procedure resolution will enable us to react quickly to the crisis symptoms in the banking sector, which should protect shareholders and creditors of banks from considerably higher losses than these losses, which they could incur if standard procedure based on insolvency law would be applied.

\section{Crisis of public finances of the state}

\section{a. Threats for public finances of Poland}

The structure of the public finances of the Polish state does not create a consistent system. In particular, fiscal burdens are imposed on citizens most often in order to finance the current financial needs of the state (Kosikowski C., 2011: 14). Control over incurred expenses lacks too. Raised for years, ideas of reforms did not lead so far to change the planning 
incomes and expenditures of the state in the direction of the so-called task budget. The methodology of counting national debt, budget deficit, or the height of GDP is not consistent with the union methodology. It allows the manipulation of these values through diverse accounting procedures.

Due to the bad condition of public finances in Poland, an eventual developing financial crisis can lead to serious consequences in the sphere of public finances, among which the most important are:

1. Exceeding prudence thresholds of the level of public debt written in art. 216 section 5 Constitution and in articles 8688 act of public finances (Act of August 27, 2009, on public finance, Journal Journal of 2009, No. 157, item 1240),

2. The possibility of suspension of payments from some union funds: Cohesion Fund, European Regional Development Fund and European Social Fund (Council Regulation (E.C.) No. 1083 laying down general provisions on the European Regional Development Fund, the European Social Fund, art. 91 and art. 92).

According to article 216 section 5 Constitution, it is not allowed to take out loans, which will lead to exceeding the written in Constitution threshold of $60 \%$ of the height of public debt in relation to GDP. Exceeding and even approaching this threshold will mean the necessity of drastic cuts of public expenditures - also through reduction of some public tasks (Kosikowski C., 2016: 12).

It is necessary to appraise positively automatism of Polish legal regulation in the scope of counteracting the phenomenon of increasing public debt (Fedorowicz M., Nizioł K., 2011: 3). Polish regulation turns out to be much more inflexible than union regulation, which allows the European Commission not to take actions towards the state, in which maximal level of public debt was admittedly exceeded. Still, it decreases sufficiently approaches to the level of $60 \%$ (Council Regulation (E.U.) No 1177/2011).

Differently than in public debt, Polish financial law does not introduce a maximal level of public deficit. The threshold of 3\% in relation to GDP results from union law. There are also regulations concerning counteracting excessive deficit of public finances, the so-called procedure of excessive deficit. Within the framework of this procedure, the Board can impose on a given state such sanctions as fine or duty of making an interest-free deposit in a given height. Poland is currently included by the procedure of excessive deficit, together with 20 other states of the European Union. The longstanding of Poland in the procedure of excessive deficit (Poland was included by it already since 2004) shows the inefficiency of actions of union institutions in this scope and the illusory character of union financial sanctions, which were not even once applied. The situation can be changed by introducing the so-called six-pack, i.e. package of directives and decrees from November 2011 introducing additional sanctions, among other things, for non-observance of budget discipline or manipulation with statistical data (Journal Acts U.E. L 306/2011).

Draft of the budget of Poland for 2013 assumes a deficit at the level of over 35 billion zlotys, which can mean exceeding the maximum level of public deficit. In keeping excessive deficit of public finances of Poland und further increase of public debt, problems with fulfilment of loan needs of state can appear.

The recipe could be buying Polish debt securities from Polish National Bank. However, as well as article 220 section 2 Polish Constitution as article 123 TFEU forbid making commitments, including loans or credits for covering budget deficit (so-called ban of monetization of debt). The justification for the introduction of such regulation is fear of creating "empty" money, which cannot be covered by any assets, which could intensify inflation (Kucharski, 2011: 31).

This rule is, however, subject to far-reaching limitations, which is the possibility of acquiring debt instruments in the secondary market, i.e. after their emission and acquisition by third parties (Kucharski, 2011: 30-31). Such interpretation of Article 123 TFEU was made by European Central Bank (Fedorowicz M., Nizioł K., 2011: 8), arguing that this provision forbids only making purchases directly from entities indicated in it and not indirectly in the secondary market. A similar direction of interpretation of the Polish Constitution can lead to using Polish National Bank to finance the current loan needs of the state, which is a longer perspective that must lead to considerable growth of inflation.

\section{b. Possibility of reaching external financial support by Poland}

Besides financial support, which foreign financial institutions (among them the International Monetary Fund plays the most important role, in which Poland has a permanent credit line) could give Poland, aid obtained from European Union could be of the greatest importance for Poland.

In principle European Union is not responsible for the obligations of member states - it is the so-called no bail-out clause contained in article 125 TFEU (Sobczyński D. 2012: 26). This principle is in force in relationships with all member states; however, in TFEU itself, there are exceptions from it concerning states, which did not adopt already common euro currency (so-called states included by derogation). Article 143 TFEU includes a rich catalogue of measures, which can be applied in difficulties with balance of payments of member states included by derogation, resulting from the common upsetting balance of payments of this state or from the character of currencies, which it has in its disposal. Especially such difficulties come into play, which can expose functioning internal markets or fulfilling common commercial policy to danger. Aid for member states, which did not adopt the euro, can take the form of: 
1. Agreed to turn to other international organizations (such as IMF).

2. Introduction of necessary measures for avoiding disturbance in commerce.

3. Giving limited credits through other member states with the consent of these states.

Poland as a member state included by derogation in the scope of introduction of the euro currency could benefit from mentioned aid, under the condition of making a proper decision by the Board.

Additionally, the aid based on provisions of the decree of the Board (E.C.) number 332/2002 (Council Regulation (E.C.) No 332/2002), which is a special instrument of financial aid for member states, which did not adopt euro currency, could be available for Poland. The condition of providing medium-term aid is a serious threat with difficulties with a current balance of payments or capital flow. The total value of loans given by the European Union is limited to 50 billion euros. So far, Hungary, Latvia and Romania (Sobczyński D. 2012: 27) benefited so far from the aid provided in decree $332 / 2002$. In the act of public finances, there is the provision allowing to benefit from this union aid. According to article 81, section 1 of this act, the State Treasury can, upon request of the Monetary Policy Council, take medium-term credits from European Community and their member states to support a balance of payments.

In the face of the Greek crisis, an instrument aimed at serving all states of the European Union, which would be in the financial crisis, so potentially also Poland, was introduced in European Union. It was based on article 122, section 2 TFEU, which says that financial aid of the union can be granted to the state, which is essentially threatened with serious difficulties due to extraordinary circumstances being out of its control. This treaty basis allowed the adoption of the decree of E.U. number 407/2010 (Council Regulation (E.U.) No 407/2010 of May 11, 2010, establishing a European financial stabilization mechanism) on the strength of which so-called European Financial Stabilisation Mechanism EFSM was established. It has at its disposal funds for up to 60 billion euro. It should be used in the case of states, which have serious economic or financial difficulties or are essentially threatened by them due to extraordinary circumstances being out of their control. It is worth paying attention to the premise of extraordinary circumstances out of control of the state, also resulting from mentioned article 122 section 2 TFEU. The current crisis is, to a large extent, a result of the non-observance of the discipline of public finances, which it is difficult to regard as a circumstance being out of the control of the state. So, granting aid for states on this basis is an overinterpretation of the union principle of solidarity and breaks TFEU (Fedorowicz M., Nizioł K., 2011: 7).

In light of these difficulties, the introduction of changes to TFEU became necessary. Based on the decision of the European Council from March 25 2011, section 3 was added to article 136 TFEU, according to which states, whose currency is the euro, can establish a stability mechanism, which is activated if it will be necessary for the protection of the stability of the eurozone as a whole (European Council Decision 2011/199 / E.U.).

On this basis, ministers of finances of eurozone states signed on February 2 2012, the treaty establishing European Stabilisation Mechanism - ESM. It came into effect on September 27 after ratifying it through the sixteenth state Germany. ESM will begin functioning on July 1 2013, replacing EFSM gradually. It will have at its disposal 80 billion euros of own capital; an additional 620 billion euro will be gained by ESM by selling bonds in international financial markets.

The introduction of ESM, although profitable for the eurozone, means for Poland a step backwards in relation to so far being in force EFSM.

Firstly, differently than EFSM, which was established on the strength of the decree of E.U. and is in force for all member states, ESM was brought to life based on an international agreement concluded only between states of the eurozone Poland is not a signatory of this agreement and did not influence its shape. This agreement, although it is related to union law (what among other things basing it on article 136 section 3 TFEU and granting some competencies to European Court of Justice and European Commission shows), does not bind Poland, however.

Secondly, Poland will not join ESM until the adoption of the common euro currency - in the contract, the possibility of joining it by states out of the eurozone (Barcz J., 2011: 12-13) was namely not provided. Until the adoption of the euro, Poland does not participate financially in ESM, does not guarantee any funds within the framework of this system, has no influence on decisions made within the framework of ESM, cannot also obtain aid from ESM. Meanwhile, funds from EFSM could serve all member states, including also Poland.

Poland can still benefit from EFSM until running out of funds from this system; however, a new mechanism - ESM is so far unavailable for it. Such shaping of ESM means strengthening of financial protection of the eurozone at simultaneous marginalization of other E.U. states. It also arouses doubts in the scope of consistency of E.U. law and fulfilment of the principle of solidarity.

A separate issue, which is worth paying attention to, is the eventual duty of Poland of joining ESM together with the adoption of the euro currency. Although it does not result from primary legislation of the E.U., it was written in point 7 of the preamble to the agreement of ESM and in article 44 of the agreement itself. Thus, it is necessary to acknowledge that new condition of joining the eurozone came into being, which is not written in TFEU (Barcz J., 2011: 12) or to 
recognize that there is no such duty, what can lead to establishing two categories of states of the eurozone - these states, which adopted ESM and these states, which did not do it. However, if Poland would not agree to join ESM and therefore guarantee the solvency of states of the eurozone threatened by bankruptcy, it would be deprived of eventual support from ESM, and its creditworthiness would be probably lower than in the case of states, which joined ESM.

Analyzing the legal character of ESM, it is necessary to distinguish the agreement of ESM from the so-called fiscal treaty, i.e. international agreement signed on March 2 2012, by 25 member states of E.U. (excepting Great Britain and the Czech Republic) (Treaty on Stability, Coordination and Governance in the Economic and Monetary Union, www.european-council.europa.eu/media/639256/16_-_tscg.pl.12.pdf). States-signatories of this agreement undertakes to tighten the discipline of public finances, among other things, through the adoption of the so-called golden rule, according to which yearly structural deficit will not exceed $0,5 \%$ GDP. Financial penalties for non-observance of the treaty, imposed by the European Court of Justice, will reach $0,1 \%$ GDP. The treaty is addressed in principle to states of the eurozone. Poland will have to join it, joining the eurozone (article 14 section 5 of the treaty), which arouses similar doubts as in ESM. Ratifying the treaty earlier, Poland will have the possibility of participation in meetings of states of the eurozone; it can also declare that only some financial provisions of the treaty (opt-in clause) bind it.

To summarizing, changes introduced currently in union law head towards tightening discipline of public finances, from the point of view of public finances in Poland should be appraised positively. The possibilities of obtaining external financial aid by Poland are also extensive, and they could include:

- Support from international financial organizations as IMF

- Support from member states of the European Union - on a similar basis as international loans given to Greece

- Support from European Union: on the basis of 143 TFEU, medium-term financial aid from decree number 332/2002, aid from European Stability Mechanism (ESM), but just after joining the eurozone by Poland, aid from the European Central Bank, which could among other things buy Polish debt Securities in the secondary market.

Until joining the eurozone, Poland will not benefit fully from all aid instruments. On the other hand, it will be not enforced to incur costs of aid for states of the eurozone, which wrestle currently with a crisis of public finances.

\section{CONCLUSION}

Unprecedented since the 1930s range of worldwide financial crisis and its relatively easy transfer between markets brings the necessity of applying extraordinary remedial actions. Poland, through its participation in European Union, seems to be relatively well protected from the effects of the financial crisis. Nonetheless, even the best legal regulations adopted in Brussels, in connection with even the most extensive aid packages, will not be able to ensure Poland sufficient protection from the crisis if Poland itself will not undertake structural reforms, especially reform of public finances. The example of Greece shows that years of negligence in this scope can lead to extraordinary unpleasant consequences as well for the state itself as for its economy and also at least citizens themselves.

\section{REFERENCES}

1. Angkinand, P., Barth, J., R., Kim, H., (2010). Spillover effects from the U.S. financial crisis: Some time-series evidence from national stock returns, (in:) Gup, B.(red.), The Financial and Economic Crises: An International Perspective, Edward Elgar Publishing Ltd.

2. Barcz, J., (2011). W sprawie formuly prawnej wprowadzenia do prawa UE Europejskiego Mechanizmu Stabilizacyjnego, Europejski Przegląd Sądowy, number 1.

3. Council Regulation (E.U.) No 1177/2011 of November 8, 2011. amending Regulation (E.C.) No 1467/97 on speeding up and clarifying the excessive deficit procedure (O.J. E.U. L 306 of November 23 2011)

4. Council Regulation (E.C.) No. 1083/2006 of July 11, 2006. laying down general provisions on the European Regional Development Fund, the European Social Fund and the Cohesion Fund and repealing Regulation (E.C.) No. 1260/1999, Journal U. U.E. L 210 of July 31, 2006.

5. Council Regulation (E.C.) No 332/2002 of February 18, 2002. establishing an instrument for medium-term financial assistance for Member States' balances of payments, OJ. U. U.E. L 53 of February 23 2002, Polish special edition: Chapter 10 Volume 003.

6. Council Regulation (E.U.) No 407/2010 of May 11, 2010. establishing the European financial stabilization mechanism, Journal U. U.E. L 118 of May 122010.

7. European Council Decision 2011/199 / E.U. of March 25, 2011. on the amendment of art. One hundred thirtysix of the treaty on the Functioning of the European Union with regard to the stability mechanism for Member States whose currency is the euro, O.J. U. U.E. L 91 of April 6, 2011.

8. European Stability Mechanism, Frequently Asked Questions on the European Stability Mechanism, January 21 2013.

9. Fedorowicz, M., Nizioł, K., (2011). Nowe tendencje $w$ europejskim prawie bankowym i finansowym $w$ kontekście kryzysu na rynkach finansowych - zagadnienia wybrane, Przegląd Ustawodawstwa Gospodarczego, nr 3. 
10. Gadomski W., (2012). Jak naprawiać banki, gdy się popsują, www.obserwatorfinansowy.p1/forma/analizy/jaknaprawiac-banki-gdy-sie-popsuja

11. Heller, J., Kotliński, K., (2012). Finanse publiczne w krajach UE-15 a uczestnictwo w strefie euro, Ekonomista, nr 2.

12. Judgment of the Court of First Instance of March 2, 2012. in joined cases T-29/10 Kingdom of the Netherlands v European Commission and T-33/10 ING Groep NV v European Commission, in which the case concerned the subscription by the Dutch State of shares in an increased share capital ING bank, www lex.pl/czytaj/lartykul/ets-o-pomocy-przyznanej-ing-z-uwagi-na-kryzys-finansowy

13. Jurkowska-Zeidler, A., (2010). Nowe ramy instytucjonalne nadzoru finansowego w Unii Europejskiej, Gdańskie Studia Prawnicze, Tom XXIV.

14. Kucharski, P., (2011). Konstytucyjny zakaz finansowania deficytu budżetowego przez NBP a prawo Unii Europejskiej, Państwo i Prawo, nr 3.

15. Kosikowski, C., (2011). Naprawa finansów publicznych w Polsce (aspekty prawne), „Państwo i Prawo, nr 7-8.

16. Łolik, M., (2012), Projekt nowych regulacji unijnych dotyczacych działalności agencji ratingowych, Przegląd Prawa Handlowego, nr 2.

17. Regulation (E.U.) No 1092/2010 of the European Parliament and of the Council of November 24, 2010, on E.U. macroprudential supervision of the financial system and establishing a European Systemic Risk Board, Journal Laws L 331 of December 152010.

18. Sobczyński, D., (2012). Ramy prawne tzw. mechanizmu greckiego oraz Europejskiego Mechanizmu Stabilności, Europejski Przeglad Sadowy, nr 2.

19. Surdej, A., Globalny kryzys finansowy - implikacje dla Polski, Tekst opublikowany na stronie: http://krakowskie.nazwa.pl/test/index.php?option=com_content\&view=article\&id=53:aleksander-surdej-qglobalny-kryzys-finansowy-implikacje-dla-polskiq\&catid=1:artykuy\&Itemid=2

20. Treaty on the Functioning of the European Union, Journal U. UE C 83 of 30 March 2010. www.eurlex.europa.eu/LexUriServ/LexUriServ.do?uri=OJ:C:2010:083:0047:0200:PL:PDF

21. Treaty on Stability, Coordination and Governance in the Economic and Monetary Union, www.europeancouncil.europa.eu/media/639256/16 - tscg.pl.12.pdf.

22. Wyciślak, S., (2012). Efekt zarażania w mechanizmie rozprzestrzeniania się kryzysu, Ekonomista, nr 2. 